\title{
Çeviri sürecinde kuram ve uygulama ilişkisi: Bartın Üniversitesi Çeviribilim Bölümü I. Sınıf İngilizce Mütercim Tercümanlık öğrencileri örneği
}

\section{Mehmet Cem ODACIOĞLU'1}

\begin{abstract}
APA: Odacıŏ̆lu, M. C. (2020). Çeviri sürecinde kuram ve uygulama ilişkisi: Bartın Üniversitesi Ceviribilim Bölümü I. Sınıf İngilizce Mütercim Tercümanlı öğrencileri örneği. RumeliDE Dil ve Edebiyat Araştırmaları Dergisi, (19), 887-902. DOI: 10.29000/rumelide.753173.
\end{abstract}

Öz

Bu çalışma, Bartın Üniversitesi Çeviribilim Bölümü İngilizce Mütercim Tercümanlık I. Sınıf öğrencilerinin 2019-2020 Güz döneminde zorunlu olarak aldıkları 14 haftalık IMT 103 Çeviri ve Çeviribilime Giriş dersi müfredatında yer alan kuramsal yaklaşımları, çeviri yöntem ve stratejilerini çeviri sürecine ne oranda yansıttığını incelemektedir. Bu maksatla dersin ilk haftasında öğrencilere ders içeriğine dair bir izlence verilmiş olup, ilk 7 hafta boyunca çeviribilim ve çeviride önemli kavramlar, terimler, kuramsal yaklaşımlar, çeviri yöntem ve stratejileri üzerinde durularak bazı örnekler sunulmuştur. Sonraki 7 hafta ise birtakım metin türleri tanıtılarak bu metinlerin ders esnasında interaktif olarak çevirileri yaptırılmış ve bir önceki haftalarda öğrenilen bilgilerin çeviri sürecine yansıtılıp yansıtılmadı̆̆ı sorgulanmıştır. Unutulmamalıdır ki salt kuram bilgisi ezberden öteye geçemediği durumda bir yararı ve işlevi olmayıp uygulamayla desteklenmesi gerekmektedir. Benzer şekilde kuram bilgisi olmadan uygulama yapmak da imkansızdır. Bu doğrultuda IMT 103 Çeviri ve Çeviribilime Giriş dersinde öğretilen her türlü kuramsal yaklaşım, çeviri yöntemi, strateji ve çeviri dünyasına ait terimlerin çeviri sürecine ne oranda yansıdığını görmek ve böylelikle sürecin kolay atlatılıp atlatılmadığını ortaya çıkarmak açısından dersin sonunda sınıftan 3 öğrenci seçilmiş ve öğrencilerden yaklaşık 1000 kelimelik Koronavirüs hakkında kısa bir tıp metnini herhangi bir makine çevirisi aracı kullanmaksızın çevirmeleri istenmiştir. Çalışma sonunda 1.sınıftan itibaren kuram ve uygulama arasında bütünlük oluşturmak gerektiği, bu bilincin en başında kazandırılması durumunda çeviri sürecinin daha kaliteli ve başarılı olacağı bulgusuna ulaşılmıştır. Zaten çeviri öğrencilerinin zihinlerinde önceden var olan kuramsal alt yapı sayesinde çeviri sürecine daha sorgulayıcı yaklaşarak ve çevirinin birçok boyutunu birden düşünerek daha başarılı bir çeviri süreci deneyimleyeceği beklenen bir durumdur. Ancak alt yapı birinci sınıftan itibaren kazandırılırsa sonraki yıllarda çeviriye olan sorgulayıcı yaklaşım artacak ve çeviri edinci daha çok gelişecektir. Bu nedenle söz konusu araştırma, 3 öğrencinin yaptığı çevirilerden de görüleceği gibi daha birinci sınıftan itibaren bunun aşlanması gerektiğini gözler önüne sermeyi hedeflemiştir.

Anahtar kelimeler: Çeviri, çeviribilim, çeviri pratiği, çeviri kuramı, çeviri süreci, Koronavirüs

\section{Theoretical and practical relationship in the translation process: The case of 1st grade English Translating \& Interpreting students at Bartin University, Translation Studies Department}

\author{
Abstract \\ This study analyzes to what extent translation students at Bartin Univertsity in the department of \\ Translation Studies (English), taking a compulsory course titled "ETI 103 Introduction to \\ oooo-0001-6627-6681 [Makale kayit tarihi: 28.02.2020-kabul tarihi: 20.06.2020; DOI: 10.29000/rumelide.753173]


Theoretical and practical relationship in the translation process: The case of 1st grade English Translating \& Interpreting students at Bartin University, Translation Studies Department / M. C. Odacıŏlu (pp. 887-902)

Translation and Translation Studies", reflect theoretical approaches, translation methods and strategies, which are the components of the above-mentioned course in the translation process. For this purpose, in the first week of the Fall semester, the student was given a curriculum about the content of the course. During the first 7 weeks important concepts, terms, theoretical approaches, translation methods and strategies in translation studies and translation were offered to students in the light of some examples. In the next 7 weeks, some text types were also introduced, and interactive translations of these texts were done during the course. It was questioned whether the information learned in the previous weeks was reflected by students in the translation process. It should here not be forgotten that purely theoretical information, if it cannot go beyond only information with no actual practice, it does not have any benefits or function. Then, this means that it should, be supported by practice. Similarly, it is also impossible to practise without theoretical information. In this respect, 3 students from the translation class at Bartin University were selected at the end of the course and were asked to translate a short medical text on Coronavirus without using machine translation to see how much they can reflect theoretical approaches, methods, strategies and concepts/terms regarding the translation world taught in the ETI 103 Translation and Translation Studies course during the translation process. At the end of the study, it was found that it is necessary to create integrity between theory and practice in translation starting from the first grade, and if the awareness is gained on translation students at the very beginning, the translation process will be more qualified and successful. It is surely an expected situation that translation students will experience a more successful translation process if he/she approaches to the process more questionably and by thinking of many other aspects of translation thanks to the theoretical infrastructure that already exists in their minds. However, if this infrastructure is acquired from the first year, the questioning approach to translation and to its process will remarkably increase in the following years of training. As a result, the translation competence will develop more. Accordingly, this research aimed to reveal that this attitude towards translation process should be started from the first grade as it can be seen from the translations carried out by 3 students.

Keywords: Translation, translation studies, translation practice, translation theory, translation process, coronavirus

\section{Giriş}

Çeviri sürecinde çevirmenin salt dilsel aktarım yapmanın ötesinde kaynak metni anlamak ve onu erek metinde anlamlandırmak, bir diğer ifade ile anlaşılır hale getirmek için uyguladığı pek çok işlem bulunmaktadır. Bu işlemlerin hepsi aslında çevirmenin çeviri edinçlerini oluşturmaktadır. O halde çevirmen bir metni çevirirken karar verici bir mekanizma olarak ve her şeyden önce uzman olarak davrandığı taktirde çeviri süreci çevirmeni değil bilakis çevirmen süreci yönlendirmektedir. Uzmanlığın ve çeviri edincinin kazanılabilmesi ise ancak uygulamayla desteklenen, bununla beraber kuramsal yaklaşımları da barındıran bir çeviri eğitimiyle mümkündür. Çevirmen adayına salt uygulama yaptırmak ve uygulamaya teşvik etmek onun benzer türde metinleri çevirdiği sürece etkili olabilir ancak işin içine farklı bir kültürü tanımak girdiğinde, salt uygulama edinci yeterli olmamaktadır. Söz gelimi çevirmen çeviri sürecine girdiği andan itibaren kafasında bazı soruların oluşmuş olması gerekmektedir: "Çeviriyi kim için ve ne amaçla yapıyorum?”, "Bu çevirinin yapılması erek okuyucuya ne katacaktır?”, "Çeviriyi yaparken kaynak kültürü anlamak için ne gibi araştırmalar ve kuramsal yaklaşımlar kullanmalıyım?”, "Kaynak metnin yazarı kaynak metni neden yazmıştır?”, "Erek metni üretirken uygulayabileceğim çeviri yöntem ve stratejileri nelerdir? Hangi kuramsal 
yaklaşımlar işlevsel ve okunur bir çeviri metin üretir?”, “Çeviri yaparken karşılaştı̆̆ım zorlukları nasıl çözebilirim?” vb.

Bu bilgiler ışı̆̆ı altında, bu çalışmada, Bartın Üniversitesi Çeviribilim Bölümü İngilizce Mütercim Tercümanlık I. Sınıf öğrencilerinin 2019-2020 Güz döneminde zorunlu olarak aldıkları 14 haftalık IMT 103 Çeviri ve Çeviribilime Giriş dersi müfredatında yer alan kuramsal yaklaşımları, çeviri yöntem ve stratejileri çeviri sürecine ne oranda yansittığı incelenmektedir. Bu doğrultuda dersin ilk haftasında öğrencilere ders içeriğine dair bir izlence verilmiştir.
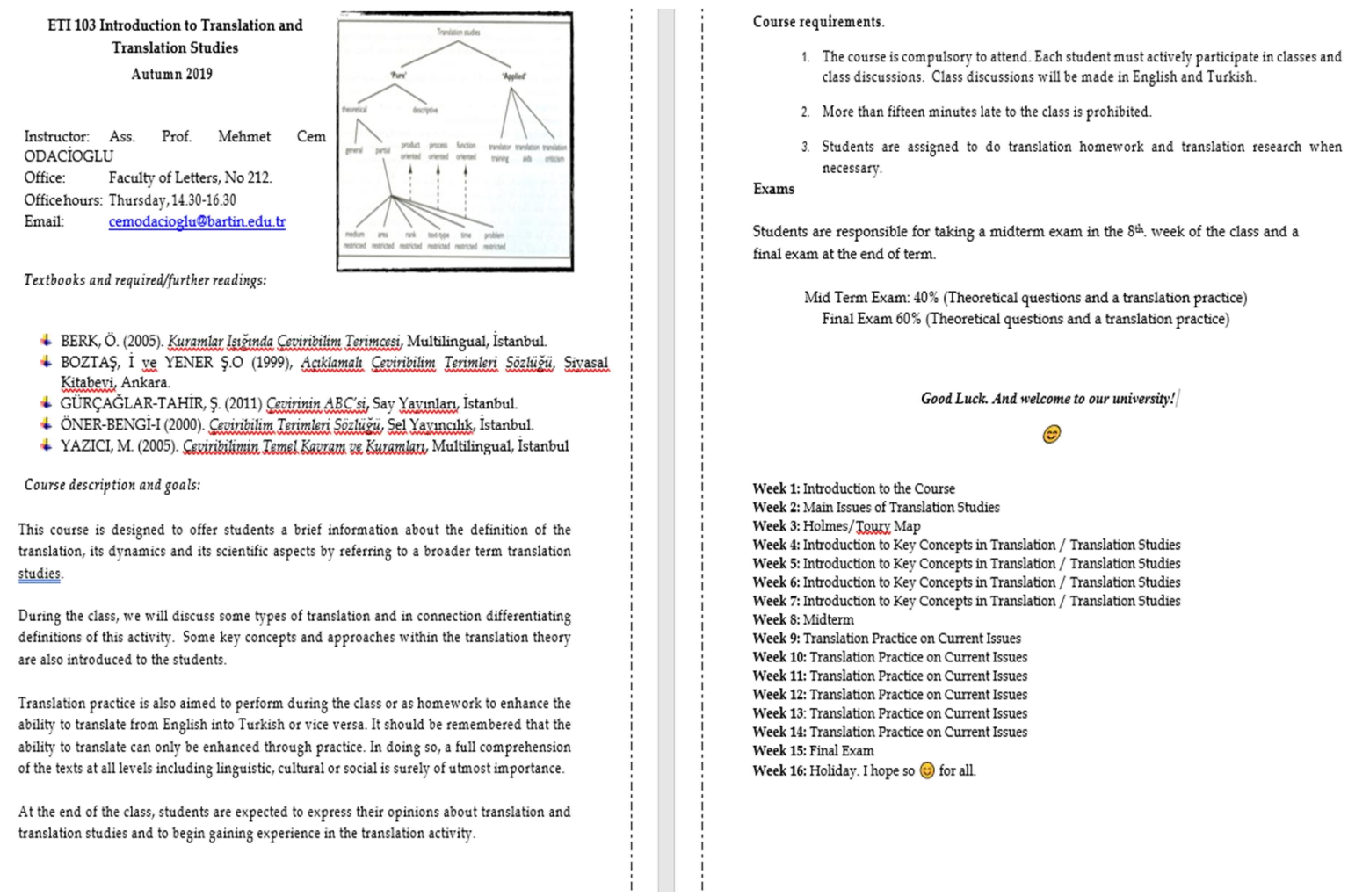

Şekil 1: IMT 103 Çeviri ve Çeviribilime Giriş izlencesi

İzlenceden de görüleceği gibi ilk 7 hafta boyunca çeviribilim ve çeviride önemli kavramlar, terimler, kuramsal yaklaşımlar, çeviri yöntem ve stratejileri² ${ }^{2}$ üzerinde durularak bazı örnekler sunulmuştur. Sonraki 7 hafta ise birtakım metin türleri üzerinden ders ortamında çeviriler yaptırılmış ve bir önceki haftalarda öğrenilen bilgilerin çeviri sürecine yansıtılıp yansıtılmadığı araştırılmıştır. Salt kuram bilgisi ezberden öteye geçemediği durumda bir yararı ve işlevi olmayıp uygulamayla desteklenmesi gerekmektedir. Benzer şekilde kuram bilgisi olmadan uygulama yapmak da imkansızdır. Bu

$2 \quad$ Kaynak metin, erek metin, kaynak kültür, erek kültür, kaynak okur, erek okur, görünürlük, görünmezlik, disiplinler arasılık, sözcüğü sözcügüne çeviri, eşdeğerlik, öyküntü (calque), ödünçleme, transliterasyon, modülasyon, uyarlama, transpozisyon, sadık çeviri, özgür çeviri, anlam çevirisi, yerlileştirme, yabancılaştırma, söylem, işlevsel çeviri, amaç odaklılık, çeviri eylemi, çeviri edinci, dil edinci, dilbilim, bağlam, içerik, bağlaşıklık, bağdaşıklık, doğrudan çeviri, dolaylı çeviri, jargon, mesleki dil, kesit dil, metin türleri, bilgilendirici metin, anlatımcı metin, işlemsel metin, deyimsel çeviri, göstergeler arası çeviri, diller arası çeviri, dil içi çeviri, kültürler arası çeviri, kültür aktarımı, dilsel aktarım, ana dili edinci, alıcı dil, anlamsal çeviri, iletişimsel çeviri, biçim, biçem, anlambilim, edimbilim, ortak zemin, Skopos, translatum, ekleme çeviri yöntemi, cümleleri bölerek aktarma vb. kavramlar derste giriş düzeyinde öğretilmiş ve örneklerle desteklenmiştir. 
doğrultuda IMT 103 Çeviri ve Çeviribilime Giriş dersinde öğretilen her türlü kuramsal yaklaşım, çeviri yöntemi ve stratejileri ve çeviri dünyasına ait terimlerin çeviri sürecine ne oranda yansıdığını görmek ve böylelikle sürecin kolay atlatılıp atlatılmadığını ortaya çıkarmak açısından dersin sonunda sınıftan gönüllü katılımcı olarak 3 öğrenci seçilmiş ve öğrencilerden yaklaşık 1000 kelimelik Koronavirüs hakkında kısa bir tıp metnini herhangi bir makine çevirisi aracı kullanmaksızın çevirmeleri

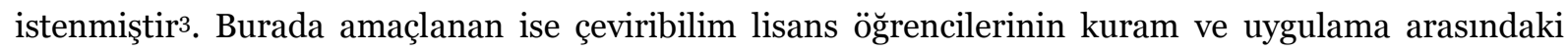
ilişkiyi somutlaştırarak uygulamada daha başarılı sonuçlar elde etmelerini sağlamaktır. Hastürkoğlu da bir çalışmasında mütercim tercümanlık lisans öğrencilerinin çeviri edinçlerini geliştirmek üzere çeviri eğitmenlerinin kuram ve uygulamalı dersleri içerek şekilde bir müfredat hazırlaması gerektiğini belirtmiştir (Hastürkoğlu, 2019: 914). Bu da kuram ve uygulama arasındaki bağlantıya işaret eden önemli bir tespittir ve ilk sınıftan itibaren giriş düzeyinde dahi olsa kuramsal bazı yaklaşımlar ve kavramların öğrencilere öğretilmesi ilerleyen dönemler için olumlu olacaktır.

\section{Çalışmanın araştırma sorunları}

- Bartın Üniversitesi Çeviribilim Bölümü 1. Sınıf Mütercim Tercümanlık Öğrencileri IMT 103 Çeviri ve Çeviribilime Giriş Dersinde öğrendikleri kuramsal yaklaşımları, çeviri yöntem ve stratejilerini çeviri sürecinde etkili olarak kullanabilmekte midir?

- Sinıftan itibaren uygulamayla desteklenen kuramsal yaklaşımların, çeviri yöntem ve stratejilerinin mütercim tercümanlı öğrencilerine öğretilmesi çeviri sürecine daha eleştirel bakılmasını ve çeviri sürecinin daha başarılı atlatılmasını sağlayabilir mi?

- Çeviri sürecinin daha başarılı atlatılması ve çeviri kalitesi açısından 1.sınıftan itibaren kuram ve uygulama arasında bütünlük oluşturmak gerekli midir?

Çalışmanın birinci bölümünde araştırmada incelenen metin koronavirüs ile ilgili olduğundan önce tıp çevirisi ile ilgili kısa bir bilgi verilecektir. Sonrasında ise koronavirüs salgını tanımlanarak tartışma/bulguların yorumlanmasını kısmını oluşturan analiz kısmına geçilecektir.

Çalışmada metne dayalı betimleyici yöntem uygulanmış olup, öğrenci çevirileri üzerinden bir değerlendirme yapılacaktır.

\section{Tıp metinleri çevirisi}

Tıp metinleri çevirisi çeviride hassas bir uzmanlık alanı olarak, çeviri sürecinde çevirmenden farklı yöntem ve stratejiler uygulamayı gerektirmektedir4. Her ne kadar bilimsel metinlerin çevirisinde kullanılan yöntem ve stratejiler tıp metinleri çevirisi için de geçerli olsa da, bu metinlerin erek okur kitlesi tarafından net anlaşılması ve sıfır hatayla yazılmış/çevrilmiş olması gerekmektedir. Zira bu metinler insan hayatını ilgilendiren konulardan bahseder ve dolayısıyla da bu metinlerdeki en ufak bir hata ve yanlış anlaşılma hastanın yanlış tedavi uygulaması vb. riskli sonuçlara yol açabileceği gibi hayati tehlikeye de neden olabilir. O halde tıp metinleri söz konusu olduğunda öncelikli olarak kaynak

3 Makine çevirisinin kullanılmasının sınırlanmasının nedeni, çevirmen adayının derste öğrendiği kuramsal yaklaşım, çeviri yöntem ve stratejilerini çeviri sürecine ne oranda yansıttığını gözlemlerken öğrendiklerini kendi bireysel süzgecinden geçirip, çeviri edincini ders öğrenme çlktıları ve öz çabasına uygun bir şekilde geliştirip geliştirmediğini görmek içindir.

4 Sözcüğü sözcüğüne çeviri, ödünçleme, transliterasyon, öyküntü, açımlama, açıklama, ekleme, çıkarma, uyarlama, modülasyon vb (krş. M. Argeg, 2015). 
metnin iyi ve hatasız yazılmış olması gerekmektedir. Çevirmen de çeviri sürecinde kaynak metni detaylı okumalı ve bilmediği terimleri koşut metinler ya da alan uzmanlarına danışarak erek metne aktarmalı, gerekirse çeviri işini en başından reddetmelidir. Bu, tıp metinlerinin çevirisinde çevirmene büyük bir iş düştüğünü göstermektedir. Çevirmen dilsel hem de kültürel bir uzman olmanın yanı sıra tıp alanında da kendini geliştirmeli ve uzman olmalıdır. Ancak bu şekilde çeviri insan hayatını riske sokmayacak şekilde yapılabilir.

Karwack’a göre, tıp çevirisi farmakoloji, cerrahi, pediatri, psikiyatri, dahiliye, onkoloji, kardiyoloji vb. pek çok alanla ilgili olarak sürdürülmektedir. O halde çeviride uzmanlık alanı olarak, tıp metinlerinin çevirisi salt tek bir metin türüyle sınırlandırılamaz ve içerdiği söylemler de homojen bir yapıda değildir. Çünkü bazı tıp metinleri tıp öğrencilerinin kullandığı ders kitaplarından tıp dünyasına yönelik popüler bilim kitapları, araştırma makaleleri, konferans bildirileri, vaka araştırmaları, raporlar, hastaları bilgilendirici broşürler, hasta onay formları ve gündelik dilde yazılmış genel geçer bilgiler sunan metinlere kadar çeşitlilik göstermektedir. Ve her bir metnin çevirisi farklı bir süreç izleyebilmektedir. Zira tıp dili akademik, profesyonel, teknik ve mesleki olmak üzere farklı bir uzmanlık dilidir. Ayrıca tıp dili pek çok Yunanca ve Latince sözlükten oluşan5 özel bir terminolojiden oluşmaktadır (2015: 272-273). Bu özel terminolojiyi öğrenmek durumunda kalan tıp çevirmenleri metnin türü, özellikleri ve erek kitlenin beklentilerine göre çeviri sürecinde hangi terimleri kullanması gerektiği bilen bir uzman olmalıdır (krş. Rigouts Terryn ve diğ., 2019: 109).

\section{Koronavirüs salgını}

T.C. Sağglık Bakanlığı Halk Sağlığı Genel Müdürlüğünde yapılan açıklamaya göre, Koronavirüsler "soğuk alginh̆ğından Orta Doğu Solunum Sendromu (MERS-CoV) ve Şiddetli Akut Solunum Sendromu (SARS-CoV) gibi daha ciddi hastahklara kadar çeşitli hastahklara neden olan büyük bir virüs ailesidir ve [K]oronavirusler zoonotik olup, hayvanlardan bulaşarak insanlarda hastahk yapabilir"6.

Koronavirüs (COVID-19 tipi), ilk defa Aralık 2019'da Çin'in Wuhan kentinde Denüz Ürünleri Toptan Satış marketinde satılan hayvanlardan kaynaklı olarak ortaya çıktığı düşünülen yeni bir koronavirüs tipidir. Virüsün hayvan kaynaklı olduğu düşünülmekle birlikte, salgın ABD dahil İran, Japonya, Tayland, İtalya gibi ülkelere de sıçramıştır ve bu süreç devam etmektedir. Hastalık grip mikrobuna benzer belirtiler göstermekte ve insanlarda, özellikle yaşlılarda bağışıklık sistemini zayıflatarak ölümlere yol açmaktadır. Henüz hastalığın tedavisiyle ilgili bir aşı geliştirilememiştir. Ancak hastalığın önlenebilmesi için uzmanlar ellerin yıkanması ve maske takılması konusunda insanlara uyarılarda bulunmaktadır7.

\section{Çeviri sürecinde kuram ve uygulama ilişkisi: Bartın Üniversitesi Çeviribilim Bölümü I. Sınıf İngilizce Mütercim Tercümanlık öğrencileri örneği}

Bu kısımda Koronavirüs hakkında yazılan İngilizce bir metnin IMT 103 Çeviri ve Çeviribilime Giriş dersini alan 3 öğrencinin ${ }^{8}$ gerçekleştirdiği Türkçe çevirileri incelenmiş ve ders içerik ve öğrenme

Ayrıca bkz. Erten, 2016 ve Çetintaş Sönmez, 2011.

2019-nCoV HASTALIĞI, Sağlık Çalışanları Rehberi, s.2 Erişim: 14.01.2020

Bkz. What you need to know about coronavirus disease 2019 (COVID-19), https://www.cdc.gov/coronavirus/2019-ncov/downloads/2019-ncov-factsheet.pdf, Erişim: 26.02.2019, A, Schwartz ve L. Graham, 2020, s.1-2.

$8 \quad$ Sinıf mevcudu 14 öğrencidir. 
Theoretical and practical relationship in the translation process: The case of 1st grade English Translating \& Interpreting students at Bartin University, Translation Studies Department / M. C. Odacıŏlu (pp. 887-902)

çıktılarının çevirmen adayları tarafından çeviri sürecine ne oranda yansıtıldığı gösterilmeye çalışılarak giriş kısmında belirtilen araştırma sorunlarına yanıt aranmıştır. Bu amaçla analize geçmeden önce dersin öğrenme çıtıları ve ders detayı tablo halinde sunulmuştur.

Tablo 1: Dersin öğrenme çıtıları ${ }^{9}$

- Bu dersi alan öğrenci çevirinin tanımı, çeviri süreci ve genel olarak çeviribilim hakkında bilgi sahibi olur.

- Bu dersi alan öğrenci çeviri pratiği yaparak çeviriye giriş yapar.

- Bu dersi alan öğrenci metin türlerini, çeviri teknikleri ve stratejilerini tanır ve metni nasıl analiz edeceğini bilir.

- Bu dersi alan öğrenci çeviribilim kuramları hakkında önsel bilgiye sahip olur.

- Dersin sonunda öğrenci çeviri sürecinde hangi kuramlardan faydalanacağını bilir ve ona göre davranır.

Tablo 2: Ders detayi ${ }^{10}$

\begin{tabular}{|c|c|c|}
\hline Dersin seviyesi & $:$ & Lisans \\
\hline Dersin tipi & : & Zorunlu \\
\hline Ön koşullar & : & Yok \\
\hline $\begin{array}{l}\text { Dersi } \quad \text { veren } \\
\text { ögretim } \\
\text { elemanlart }\end{array}$ & : & Doç. Dr. Mehmet Cem ODACIOĞLU \\
\hline Dersin amace & : & $\begin{array}{l}\text { Bu dersin amacı çevirmen adayının çeviri uygulamalarına giriş yapılarak metin } \\
\text { çözümlemeyi öğrenmesi ve metnin biçim, biçem, içerik, işlev, bilgi verici vb. } \\
\text { bağlamda bilgilenmesidir. }\end{array}$ \\
\hline Dersin içeriği & $:$ & $\begin{array}{l}\text { Bu derste öğrenci metin çözümlemeyi öğrenir ve biçim, biçem, işlev, içerik, bilgi } \\
\text { verici ve işlevsekl metinler bağlamında adım adım çeviri uygulamalarına girilir. } \\
\text { Çeviri kuram ve uygulamaları başlangıç düzeyinde ele alınır. Metin türleri ve bu } \\
\text { türlerle ilgili çeviri teknikleri üzerinde durulur. Alıştırmalar ve yazılı ödevler yoluyla } \\
\text { öğrenme çıktıları ölçülür. Çeviri alanı konusunda üst bakış kazandırılması, alanın } \\
\text { kavramlarının öğretilmesi, çevirinin tanımının, çeviri sürecinin ve çevirmenin bu } \\
\text { süreçteki rolünün öğretilmesi dersin hedefleri arasındadır. Böylelikle öğrencinin } \\
\text { çeviri alanını ve çevirmenliği tanıması sağlanır ve çevirmen adayı yetişeceği } \\
\text { uzmanlık alanının özelliklerini kavrayabilecek donanıma sahip olur. }\end{array}$ \\
\hline $\begin{array}{l}\text { Planlanan } \\
\text { öğrenme } \\
\text { etkinlikleri } \\
\text { öğretme } \\
\text { ÿ̈ntemleri }\end{array}$ & : & Tartışma , uygulama ve soru cevap \\
\hline $\begin{array}{l}\text { Ders için önerilen } \\
\text { diğer hususlar }\end{array}$ & : & $\begin{array}{l}\text { Bu derste öğrencilerin ders dışı konuyla alakalı okuma yapması ve alıştırma } \\
\text { yapması beklenir. }\end{array}$ \\
\hline
\end{tabular}

9 http://ubys.bartin.edu.tr/AIS/OutcomeBasedLearning/Home/CourseDetail?\&isElectiveCourse= false\&isIntegratedCourse $=$ false $\&$ courseId $=33826 \&$ curriculumId $=500748 \&$ apid $=512 \&$ eqd $=10602 \& \mathrm{progNa}$ me=Edebiyat\%20Fak\%C3\%BCltesi\%20-

\%20\%С3\%87eviribilim\%2oB\%C3\%B61\%C3\%BCm\%С3\%BC\%2o/\%20\%C3\%87eviribilim\%2oPr.\%2o(\%C4 \%Bongilizce) Erişim: 25.02.2020

10 http://ubys.bartin.edu.tr/AIS/OutcomeBasedLearning/Home/CourseDetail?\&isElectiveCourse= false\&isIntegratedCourse $=$ false $\&$ courseId $=33826 \&$ curriculumId $=500748 \&$ apid $=512 \&$ eqd $=10602 \&$ progNa me=Edebiyat\%20Fak\%C3\%BCltesi\%20-

\%20\%C3\%87eviribilim\%20B\%C3\%B61\%C3\%BCm\%C3\%BC\%20/\%20\%C3\%87eviribilim\%2oPr.\%20(\%C4 \%Bongilizce) Erişim: 25.02.2020 


\begin{tabular}{|l|l|}
\hline Dersin verilişi & Yüz yüze \\
\hline
\end{tabular}

Tablo 3: Koronavirüs hakkındaki İngilizce metin ${ }^{11}$

\section{What is a "novel" coronavirus?}

A novel coronavirus ( $\mathrm{CoV}$ ) is a new strain of coronavirus that has not been previously identified in humans. The new, or "novel" coronavirus, now called 2019-nCoV, had not previously detected before the outbreak was reported in Wuhan, China in December 2019.

Is the new virus the same as SARS?

No, 2019-nCoV is from the same family of viruses as Severe Acute Respiratory Syndrome (SARS-CoV) but it is not the same virus.

\section{How dangerous is it?}

As with other respiratory illnesses, infection with 2019- $n C o V$ can cause mild symptoms including a runny nose, sore throat, cough, and fever. It can be more severe for some persons and can lead to pneumonia or

breathing difficulties. More rarely, the disease can be fatal. Older people, and people with pre-existing medical conditions (such as, diabetes and heart disease) appear to be more vulnerable to becoming severely ill with the virus.

\section{Can humans become infected with the 2019-nCoV from an animal source?}

Detailed investigations found that SARS-CoV was transmitted from civet cats to humans in China in 2002 and MERS-CoV from dromedary camels to humans in Saudi Arabia in 2012. Several known coronaviruses are circulating in animals that have not yet infected humans. As surveillance improves around the world, more coronaviruses are likely to be identified

The animal source of the 2019-nCoV has not yet been identified. This does not mean you can catch 2019$n C o V$ from any animal or from your pet. It's likely that an animal source from a live animal market in China was responsible for some of the first reported human infections. To protect yourself, when visiting live animal markets, avoid direct unprotected contact with live animals and surfaces in contact with animals.

The consumption of raw or undercooked animal products should be avoided. Raw meat, milk or animal organs should be handled with care, to avoid cross-contamination with uncooked foods, as per good food safety practices

\section{Can the 2019-nCoV be transmitted from person to person?}

Yes, the 2019- $n \mathrm{CoV}$ causes respiratory disease and can be transmitted from person to person, usually after close contact with an infected patient, for example, in a household workplace, or health care cent.

\section{Who can catch this virus?}

People living or travelling in an area where the 2019-nCoV virus is circulating may be at risk of infection. At present, 2019-nCoV is circulating in China where the vast majority of people infected have been reported. Those infected from other countries are among people who have recently traveled from China or who have been living or working closely with those travellers, such as family members, co-workers or medical professionals caring for a patient before they knew the patient was infected with 2019-nCoV.

Health workers caring for persons who are sick with 2019-nCoV are at higher risk and must protect themselves with appropriate infection prevention and control procedures.

WHO is continuously monitoring the epidemiology of this outbreak to better understand where the virus is circulating and how people can protect themselves from infection. For more information, see WHO's latest situation reports.

\section{Who is at risk of developing severe illness?}

While we still need to learn more about how 2019-nCoV affects people, thus far, older people, and people with pre-existing medical conditions (such as diabetes and heart disease) appear to be more at risk of developing severe disease.

\section{How does the virus spread?}

The new coronavirus is a respiratory virus which spreads primarily through contact with an infected person through respiratory droplets generated when a person, for example, coughs or sneezes, or through droplets of saliva or discharge from the nose. It is important that everyone practice good respiratory hygiene. For example, sneeze or cough into a flexed elbow, or use a tissue and discard it immediately into a closed bin. It is also very important for people to wash their hands regularly with either alcohol-based hand rub or soap and water.

11 https://www.who.int/news-room/q-a-detail/q-a-coronaviruses Erişim: 05.01.2020

Adres

Kurklareli Üniversitesi, Fen Edebiyat Fakültesi, Türk Dili ve Edebiyatı Bölümü, Kayalı Kampüsü-Kırklareli/TÜRKIYE e-posta: editor@rumelide.com 
Theoretical and practical relationship in the translation process: The case of 1st grade English Translating \& Interpreting students at Bartin University, Translation Studies Department / M. C. Odacıŏlu (pp. 887-902)

Tablo 4: Öğrencinin gerçekleştirdiği koronavirüs hakkındaki Türkçe çeviri metin 1

\begin{tabular}{|c|}
\hline Yeni Corona virüsü nedir? \\
\hline $\begin{array}{l}\text { Yeni Corona virüsü, daha önce insanlarda görülmemiş olan yeni bir Corona çeşididir. Şimdiki adı 2019-nCoV } \\
\text { olan bu yeni veya hiç görülmemiş Corona virüsü, Aralık 2019'da Çin’in Vuhan şehrindeki salgından önce } \\
\text { keşfedilmemiştir. }\end{array}$ \\
\hline Yeni virüs SARS ile aynı mı? \\
\hline $\begin{array}{c}\text { Hayır, 2019-nCoV virüsü Şiddetli akut solunum yolu sendromu (SARS-CoV) virüsleri ile aynı aileden gelir } \\
\text { ancak aynı virüs değildir. }\end{array}$ \\
\hline Virüs ne kadar tehlikeli? \\
\hline $\begin{array}{l}\text { Diğer solunum hastalıklarında da olduğu gibi 2019-nCoV enfeksiyonu; burun akıntısı, boğaz ağrısı, öksürük ve } \\
\text { ateş gibi hafif semptomlara sebep olabilir. Bazı kişilerde daha şiddetli olabilir ve zatürre veya nefes darlı̆ına yol } \\
\text { açabilir. Çok nadiren ise hastalık ölümcül olabilir. Yaşlı insanların ve daha önceden kalp rahatsızlığı veya } \\
\text { diyabet gibi sağlık problemleri olan kişilerin virüse karşı daha hassas olduğu ve daha şiddetli hasta } \\
\text { olabilecekleri söylenebilir. }\end{array}$ \\
\hline İnsanlar 2019-nCoV virüsünü bir hayvandan kapabilirler mi? \\
\hline $\begin{array}{l}\text { Detaylı araştırmalar SARS-CoV virüsünün } 2002 \text { yılında Çin'de misk kedilerinden insanlara, } 2012 \text { yılında ise } \\
\text { Suudi Arabistan'da çöl develerinden insanlara bulaşmış olduğunu tespit etti. Bilinen birçok Corona virüsü, } \\
\text { henüz insanlara bulaşmamış olan hayvanların kan dolaşımı içerisinde. Denetlemeler dünya çapında geliştikçe } \\
\text { daha çok Corona virüsünün tespit edilmesi olası. 2019-nCoV virüsünün hayvan kaynağı henüz tanımlanmadı. } \\
\text { Bu, herhangi bir hayvandan veya evcil hayvanınızdan 2019-nCoV virüsü kapabileceğiniz anlamına da gelmez. } \\
\text { Büyük olasılıkla, bildirilen ilk insan enfeksiyonlarının bazılarından Çin'deki bir petshopta bulunan hayvan } \\
\text { kaynağı sorumlu. Petshopları ziyaret ederken kendinizi korumak için hayvanlarla temas halindeki yüzeylerden } \\
\text { ve hayvanlarla direkt olarak korunmasız temastan kaçının. Çiğ veya az pişmiş hayvan ürünlerinin tüketiminden } \\
\text { kaçınılmalıdır. Pişmemiş yemeklerle çapraz bulaşmayı engellemek için çiğ et, süt ve hayvan organları iyi } \\
\text { yiyecek güvenliği uygulamalarınca özenle tutulmalı. }\end{array}$ \\
\hline 2019-nCoV virüsü kişiden kişiye bulaşabilir mi? \\
\hline $\begin{array}{c}\text { Evet, 2019-nCoV genellikle ev ve iş yeri veya sağllk ocağı gibi yerlerde enfeksiyonlu hastayla olan yakın } \\
\text { temastan sonra kişiden kişiye geçebilir. }\end{array}$ \\
\hline Kimler bu virüsü kapabilir? \\
\hline $\begin{array}{l}\text { 2019-nCoV virüsünün dolaşım yaptı̆̆ı alanlarda yaşayan veya seyahat eden insanlar enfeksiyon riski içerisinde } \\
\text { olabilir. Virüs şu anda Çin'de enfeksiyonu kapmış büyük çoğunluğun rapor edildiği yerde dolaşım yapıyor. } \\
\text { Diğer ülkelerden olup bu virüsü kapmış kişiler, son zamanlarda Çin'e seyahat etmiş veya bu seyahat eden } \\
\text { kişilerle yaşayan ya da yakın olarak çalışan kişiler arasındadır. Buna örnek olarak aile üyeleri, iş arkadaşları } \\
\text { veya hastanın 2019-nCoV virüsü kaptığını bilmeden önce o hastayla ilgilenen sağlık uzmanları verilebilir. }\end{array}$ \\
\hline $\begin{array}{c}\text { Corona virüsünü kapmış olan hastalarla ilgilenen sağlık personelleri büyük bir risk altındadır ve kendilerini } \\
\text { uygun enfeksiyon önlemleri, kontrol prosedürleriyle korumaları gerekmektedir. Kim bu virüsün nerede } \\
\text { dolaşım yaptığını daha iyi anlayabilmek ve insanların kendilerini bu virüsten nasıl korumaları gerektiğini } \\
\text { bulabilmek için sürekli olarak bu salgının epidemiyolojisini gözlemliyor? Daha fazla bilgi için son durumun } \\
\text { bildirdiklerine bakalım. }\end{array}$ \\
\hline Kim şiddetli bir şekilde bu hastalığa yakalanma riski içerisinde? \\
\hline $\begin{array}{c}\text { 2019-nCoV'un insanları nasıl etkilediğine dair hâlâ öğrenmemiz gereken şeyler var ancak şimdiye kadar } \\
\text { edinilen bilgilerle şunu söyleyebiliriz ki yaşlılar ve daha önceden tıbbi sorunu olan kişiler (diyabet ve kalp } \\
\text { hastalıkları gibi) bu ağır hastalığa yakalanmaya daha meyilliler. }\end{array}$ \\
\hline Virüs nasıl yayılıyor? \\
\hline $\begin{array}{c}\text { Yeni Corona virüsü; öncelikle bir kişi öksürdüğünde veya hapşırdı̆̆ında, tükürük damlacıkları ya da burun } \\
\text { akıntısı yoluyla, enfeksiyonlu kişiyle temasta bulunulduğunda meydana gelen solunum damlacıkları aracıllı̆ıyla } \\
\text { yayılan bir solunum virüsüdür. Herkesin iyi bir solunum hijyenine sahip olması çok önemlidir. Örneğin } \\
\text { bükülmüş dirseğinizin içine doğru hapşırın, öksürün veya kağıt peçete kullanıp hemen sonrasında onu kapalı } \\
\text { bir çöp kutusuna atın. Ayrıca ellerin düzenli olarak ya alkoz bazlı bir el dezenfektanıyla ya da su ve sabunla } \\
\text { yıkanması çok önemlidir. }\end{array}$ \\
\hline
\end{tabular}

Tablo 5: Öğrencinin gerçekleştirdiği koronavirüs hakkındaki Türkçe çeviri metin 2

\section{'Yeni' koronavirüis nedir?}

Yeni koronavirüs, daha önce insanlarda tespit edilmemiş bir koronavirüs türüdür. Şimdilerde 2019-nCoV olarak adlandırılan koronavirüs, Aralık 2019'da Çin’in Wuhan kentinde salgının bildirilmesinden önce hiç tespit edilmemişti.

SARS virüsüyle aynı mı? 
Hayır, 2019-nCoV virüsü, SARS (Ă̆ır Akut Solunum Yetmezliği Sendromu) ile aynı virüs ailesindendir fakat aynı virüs değildir.

\section{Ne kadar tehlikeli?}

Diğer solunum hastalıklarında olduğu gibi 2019-nCoV virüsü, burun akıntısı, boğaz ağrısı, öksürük ve ateş dahil hafif semptomlara yol açabilir. Bu durum bazı kişiler için daha şiddetli olabilir ve zatürre ve nefes alma zorluklarına da yol açabilir. Daha nadiren, bu hastalık ölümcül olabilir. Yaşlı insanlar ve önceden tıbbi durumları var olan (diyabet ve kalp hastalığı gibi) kişiler virüse karşı ciddi şekilde yakalanmaya hassas görünmektedirler.

\section{İnsanlara bir hayvan kaynağından 2019-nCoV virüsü bulaşabilir mi?}

Ayrıntılı araştırmalar SARS-CoV virüsünün 2002'de Çin'de misk kedilerinden insanlara ve MERS-CoV virüsünün de 2012'de Suudi Arabistan'da tek hörgüçlü develerden insanlara bulaştığını buldu. Henüz insanlara bulaşmamış bilinen birkaç koronavirüs, hayvanlar arasında dolaşmaktadır. Gözetim dünya çapında geliştikçe daha fazla koronavirüsün tespit edilmesi muhtemel olacak.

2019-nCoV virüsünün hayvan kaynağı henüz tespit edilemedi. Bu, 2019-nCoV virüsüne herhangi bir

hayvandan veya evcil hayvanınızdan dolayı yakalanacağınız anlamına gelmiyor. Çin'deki canlı hayvan pazarındaki bir hayvan kaynağının bildirilen bazı enfeksiyonlardan sorumlu olması muhtemel. Kendinizi korumak için, canlı hayvan pazarını ziyaret ettiğinizde canlı hayvanlarla ve hayvanlara temas eden yüzeylere karşı doğrudan korumasız temastan kaçının.

Çiğ veya az pişirilmiş hayvan ürünlerinin tüketiminden kaçınılmalıdır. Çiğ et, süt veya hayvan organları, iyi gıda güvenliği uygulamalarına göre pişmemiş gıdalarla çapraz kontaminasyonu önlemek için dikkatle kullanılmalıdır.

2019-nCoV virüsü insandan insana bulaşabilir mi?

Evet, 2019-nCoV virüsü solunum hastalıklarına sebep olur ve genellikle enfeksiyonlu hasta ile yakın temastan sonra, örneğin bir işyerinde veya sağllk merkezinde insandan insana bulaşabilir.

\section{Virüse kimler yakalanabilir?}

2019-nCoV virüsünün olduğu bölgede yaşayan ve seyahat eden insanlar enfeksiyon riski taşıabilir. Günümüzde 2019-nCoV virüsü enfekte kişilerin büyük bir çoğunluğunun bildirildiği Çin'de dolaşıyor.

2019-nCoV virüsü olan hastalara bakan sağlık çalışanları daha yüksek risk altındadır ve uygun enfeksiyon önleme ve kontrol prosedürleriyle kendilerini korumalıdır.

WHO, virüsün nerde dolaştığını ve insanların kendilerini enfeksiyondan nasıl koruyacağını daha iyi anlamak için bu salgının epidemiyolojisini sürekli olarak izliyor. Daha fazla bilgi için WHO’nun son durum raporlarına bakın.

\section{Virüs nasıl yayılır?}

Yeni koronavirüs, esas olarak enfekte olmuş bir kişiyle temas yoluyla, örneğin bir kişi öksürdüğünde veya hapşırdığında ortaya çıkan solunum damlacıkları yoluyla veya tükürük damlacıkları veya burundan akıntı yoluyla yayılan bir solunum virüsüdür. Herkesin iyi bir solunum hijyeni uygulaması önemlidir. Örneğin bükülmüş bir dirseğe hapşırın veya öksürün veya bir peçete kullanın ve hemen onu kapalı bir çöp kutusuna atın. Elleri düzenli olarak su ve sabunla yıkamak da insanlar için çok önemlidir.

Tablo 6: Öğrencinin gerçekleştirdiği koronavirüs hakkındaki Türkçe çeviri metin 3

\section{Yeni tip koronavirüsüne dair merak edilenler}

Bu yazımızda koronavirüsüne dair merak edilenler hakkında bahsedeceğiz. Yazımızda bulabileceğiniz başlıklar şunlar;

- Yeni tip koronavirüsü nedir?

- Bu yeni virüs şiddetli akut solunum yolu sendromu ile aynı mı?

- Ne kadar tehlikeli bir virüsten bahsediyoruz?

- Koronavirüsü insanlara hayvanlardan bulaşır mı?

- Koronavirüsü insandan insana geçer mi?

- Kimler virüse yakalanabilir?

- Kimler ağır hastalık geçirme riski altındadır?

- Virüs nasıl yayılır?

1) Yeni tip koronavirüsü nedir?

Yeni tip koronavirüsü daha önce insanlarda tespit edilmemiş bir koronavirüsü tipidir. Yeni yada güncel koronavirüsüne (günümüzde 2019-nCov diye adlandırılır) 2019 da Çin’in Wuhan kentindeki salgından önce rastlanilmadı. 
Theoretical and practical relationship in the translation process: The case of 1st grade English Translating \& Interpreting students at Bartin University, Translation Studies Department / M. C. Odacioğlu (pp. 887-902)

Hayır. Koronavirüsü Şiddetli Akut Solunum Yolu Sendromu ile aynı ailesindendir ama aynı virüs değildir.

\section{3) Ne kadar tehlikeli bir virüsten bahsediyoruz?}

Diğer solunum yolu hastalıklarında olduğu gibi, Koronavirüsünde de burun akıntısı, boğaz ağrısı, öksürük ve ateş dahil olmak üzere hafif belirtiler görülebilir. Bu virüs kişiden kişiye göre daha şiddetli olabilir ve zatürre yada nefes problemlerine yol açabilir. Daha nadiren bu hastalı ölümcül olabilmektedir. Yaşı geçkin insanlar ve önceden mevcut hastalıkları (diyabet ve kalp hastalığı gibi) olan kişilerde ağır hastalık geçirme riski daha fazladir.

\section{4) Koronavirüsü insanlara hayvanlardan bulașır mı?}

Detaylı araştırmalar sonucunda Koronavirüsü, bir misk kedisinden(2) insanlara 2002 yılında Çin'de ve bir çöl devesinden Suudi Arabistanda insanlara bulaştığı tespit edilmiştir. Bilinen birkaç Koronavirüsü hayvanlarda dolaşmaya devam etmektedir ki buda henüz insanları etkilememiştir. Dünya genelinde keşifler geliştiğinden, daha fazla Koronavirüsü tanımlanması mümkündür. Koronavirüsünün kaynağının hangi hayvan olduğu henüz tespit edilmemiştir. Bu evinizdeki kedi köpek gibi evcil hayvanınızda Koronavirüsü kapacağınız anlamına gelmez, korkmanıza gerek yok. Çindeki canlı hayvan pazarının, rapor edilen ilk enfeksiyonlardan sorumlu olması muhtemel. Kendinizi korumak için, canlı hayvan satan yerleri ziyaret ettiğinizde, hayvanların temas ettiği yüzeylerle temas etmekten ve hayvanlarla korumasız direk temastan kaçının.

Az veya pişmemiş hayvansal gıda kullanmaktan uzak durulmalı, çiğ et, süt veya hayvan sakatatları dikkatle muhafaza edilmeli ki çapraz bulaşmadan korunabilmeli(3) ,ayrıca sadece bunun içinde değil gıdanın güvenli bir gıda olabilmesi içinde gıdayı doğru muhafaza etmeliyiz.

\section{5) Koronavirüsü insandan insana geçer mi?}

Evet. Koronavirüsü solunum yolu hastalıklarına sebep olur ve insandan insana bulaşabilir, genellikle enfekte olmuş (virüs kapmış) bir hastayla yakın temastan sonra.

\section{6) Kimler virüse yakalanabilir?}

Virüsün olduğu yerde yaşayan yada o bölgelere seyahat eden kişilerin virüse yakalanma riskleri vardır. Son zamanlarda Koronavirüsü, virüsten etkilenen insanların büyük çoğunun bildirildiği Çinde dolaşmaya devam ediyor. Diğer ülkelerdeki virüsten etkilenen kişiler arasında, son zamanlarda Çine seyahat eden birisi, yahut bu

seyyahlarla yaşayan veya çalışan kişiler, örnek verecek olursak aile üyeleri, iş arkadaşları yada sağlık çalışanlarının Koronavirüsü bulaştığını bilmeden önce ki temasları.

Koronavirüsü hastaları ile ilgilenen sağlık çalışanları daha fazla risk taşıyor ve kendilerini uygun, enfeksiyon önleyici ekipmanlarla korumaladırlar.

Dünya Sağlık Örgütü virüsün nerede dolandığını ve insanların kendilerini enfeksiyondan nasıl koruyacağını daha iyi anlamak için bu salgının epidemiyolojisini(4) sürekli olarak takip etmektedir. Daha fazla bilgi için

DSÖ’nün en son durum raporlarına bakabilirsiniz.

7) Kimler ă̆ır hastalık geçirme riski altındadır?

Hala Koronavirüsünün insanları nasıl etkilediği hakkında daha fazla bilgi edinmemiz gereksede, bu zamana kadar yaşı geçkin insanlar ve önceden mevcut hastalıkları ( diyabet ve kalp rahatsızlığı gibi) olan kişilerde ağır hastalık geçirme riski daha fazladır.

\section{8) Virüs nasıl yayılır?}

Yeni Koronavirüsü bir üst solunum yolu virüsüdür. Buda öncelikli olarak virüse sahip birisiyle temas yoluyla, örneğin bir kişi öksürdüğünde veya hapşırdığında ortaya çıkan respirator damlacıkları (solunum damlacıkları) ,tükürük damlacıkları veya burunda akıntı yoluyla yayılan bir virüs türüdür. Herkesin hijyen kurallarının gerektirdiklerini yerine getirmesi büyük önem arz ediyor. Örneğin hapşırınca veya öksürünce dirsek içi kullanılmalı yada peçete kullanıp sonrasında acilen kapalı bir çöpe atmak riski azaltan şeylerdendir. Ayrıca düzenli el yıkamayı da unutmamalıyı. Alkol bazlı antiseptik jeller yada su ve sabun ile ellerimizi yıkamalıyı.

\section{9) Antibiyotikler koronavirüsünü önlemede veya iyileştirmede etkili midir?}

Hayır. Antibiyotikler virüslere karşı işe yaramaz sadece bakteri sebepli hastalıklara karşı işe yararlar. Yeni Tip Koronavirüsü bir virüstür ve bu yüzden hastalığı önlemek veya iyileştirmek için antibiyotik kullanılmamalıdır.

\section{Bakınız}

(1) Akut Tıp bilimlerinde akut terimi ya "hızlı başlayan " ya da "kısa süreli " hastalıkları, bazen de her iki durumu birden tanımlamak için kullanır. Bu sıfat pek çok hastalığın tanımının bir parçasıdır ve bu yüzden bu hastalıkların isimlerinde yer alır. Örneğin akut lösemi ya da akut Akut Romatizmal Ateş gibi. Akut, kronik teriminin tam karşit anlamındadır.

Akut terimi halk arasında sıklıkla "şiddetli" ya da "ciddi" terimleri ile karıştırılmaktadır. Akut terimi tamamen farklı bir anlam ifade eder ve bir hastalık akut olabilir ama şiddetli olması gerekmez.

(2) Misk kedisi, (civet cat) viverridae familyasından kediye benzeyen kısa bacaklı bazı etçil memeli hayvanların ortak adıdır. Hem erkek hem de dişi misk kedilerinin perineal bölgesinde bulunan bazı bezlerde, kuvvetli bir 
kokusu olan bir madde salgılanmaktadır. Eski hint tıbbında bu hayvanların öldürülerek salgı bezleri alındığı ve ilaç yapımında kullanıldığı bilinmektedir. Dünyanın en özel ve pahalı kahvesi olan kopi luwak üretimi için vazgeçilmez olan kedi cinsidir. Bu kahve bu hayvanın dışkısından çıkan kahve çekirdekleri ile yapılır.

(3) Çapraz bulaşma, zararlı bakteri ve virüslerin kontamine bir yüzeyden başka bir yüzeye geçişidir.

(4) Epidemiyoloji, toplumdaki hastalık, kaza ve sağlıkla ilgili durumların dağılımını, görülme sıklıklarını ve bunları etkileyen belirteçleri inceleyen bir tıp bilimi dalıdır. Sağlı̆ı geliştirmek ve hastalıkları azaltmak için sağlik bilgilerini toplamak, yorumlamak ve kullanmak bu bilim dalının amaçlarındandır.

\section{Analiz ve bulgular}

\section{İlk çeviri incelendiğinde;}

Öğrencilerin gerçekleştirdiği çeviriler içerisinden ilk çeviri incelendiğinde,

\section{"A novel coronavirus (CoV) is a new strain of coronavirus that has not been previously identified in humans" ifadesi erek dile}

\section{"Yeni Corona virüsü, daha önce insanlarda görülmemiş olan yeni bir Corona çeşididir" şeklinde aktarılmıştır.}

Öğrenci burada "yeni bir koronavirüs suşu" demek yerine "yeni bir Corona çeşidi" diyerek Corona sözcügünü erek dilde ödünçleyerek (borrowing) bırakmıştır. Bununla birlikte "strain" sözcügünnün tıp dilindeki karşıllğı olan suş yerine çeşit, Coronavirus yerine ise "virüs” sözcüğünü atarak kısaltmaya gitmiş ve "Corona" ifadesini tercih etmiştir.

Öğrenci kaynak metinde yer alan "breathing difficulties" ifadesi için anlam çevirisi yaparak Türkçe metinde nefes darlığı demeyi tercih etmiştir.

Çeviri öğrencisi ayrıca "pre-existing medical conditions" ifadesini erek dile "daha önceden kalp rahatsızlı̆̆ veya diyabet gibi sağllk problemleri” şeklinde aktararak, kaynak metinde parantez içindeki ("such as, diabetes and heart diease)" ifadeleri parantezden çıkarmayı tercih etmiş ve bununla birlikte "medical conditions" sözcügünün karşıllğı olarak "sağllk problemleri” ifadesini kullanmıştır. Burada çeviri öğrencisinin anlamına göre veya bağlamsal çeviri yaptığı söylenebilir.

Çeviri öğrencisi ayrıca "appear to be more vulnerable to becoming severely ill with the virüs" ifadesini erek dilde "virüse karşı daha hassas olduğu ve daha şiddetli hasta olabilecekleri” şeklinde cümleyi ikiye bölerek aktarmıştır.

Çeviri öğrencisi “Can the 2019-nCoV be transmitted from person to person?" başlı̆̆ındaki "the 2019$\mathrm{nCoV}$ causes repiratory disease and can be contaminated from person to person, usullay after close contact with an infected patient, for example, in a household workplace, or health care cent" ifadesini erek dile aktarırken "2019-nCoV, genellikle ev ve iş yeri veya sağllk ocağı gibi yerlerde enfeksiyonlu hastayla olan yakın temastan sonra kişiden kişiye geçebilir" şeklinde aktarmış ve "causes respiratory disease" ifadesini erek dilde çıarmayı tercih etmiştir. Bunun nedeni zaten metnin başında bu virüsün bir solum hastalı̆̆ı olmasından kaynaklı olabilir.

Çeviri öğrencisi "such as family members, co-workers or medical professionals caring for a patient before they knew the patient was infected with 2019-nCoV” ifadesini Türkçe çeviride cümle haline 
getirerek "Buna örnek olarak, aile üyeleri, iş arkadaşları veya hastanın 2019-nCoV virüsü kaptığını bilmeden önce o hastayla ilgilenen sağlık uzmanları verilebilir” şeklinde aktarmıştır.

"Epidemiology” sözcüğü transliterasyon yoluyla erek dilde” epidemiyoloji” şeklinde aktarılmıştır.

"It is also very important for peaple to wash their hands regularly eith either alcohol based hand rub or soap and water" ifadesi erek dilde "Ayrıca ellerin düzenli olarak ya alkol bazlı bir el dezenfektanıla ya da su ve sabunla yıkanması çok önemlidir” şeklinde aktarılmış kaynak metindeki aktif cümle erek metinde edilgen bir yapıyla verilmiştir. (Modülasyon).

Genel olarak çeviri öğrencisinin daha birinci sınıfta zor sayılabilecek tıp çevirisiyle ilgili bir metni çevirebilmesi zor görünmektedir. Çeviri öğrencisinin genel olarak erek metinde kaynak metnin anlamını verdiği, sözcü̆üu sözcüğüne çeviri yaklaşımı ağırlıkta anlam çevirisine de başvurduğu ve $I M T$ 103 Çeviri ve Çeviribilime Giriş Dersinde öğretilen yaklaşımları erek metne yansıttığı söylenebilir. Ancak derste örneklerle giriş düzeyinde gösterilen bu yaklaşımların daha çok pratiğe dökülmesi gerekmektedir. Zira öğrenci sözcüğü sözcüğüne çeviri yaklaşımı ve diğer farklı yöntemleri kullanarak öğrendiklerini uygulamaya dökebilse de zaman zaman tıp çevirisi alanında uzman olmadığından bazı hatalar da yapmıştır'12. Söz gelimi "live animal market" ifadesi için "petshop" demiştir. Oysa metinde kastedilen canlı hayvan pazarıdır. Bazı cümleler devrik ve anlaşılmaz bırakılmıştır. Kaynak metin "Dünya Sağlık Örgütünün” sayfasından alınmıştır. Çeviri öğrencisi muhtemelen WHO kısaltmasını bilmediğinden ya da zihinsel bir karmaşadan ötürü "Kimler bu Virüsü Kapabilir" başlı̆̆ı altında bulunan "WHO is continously monitoring..." ifadesini erek dile "Kim gözlemliyor?" şeklinde aktarmıştır. Oysa burada ifade edilen Dünya Sağlık Örgütüdür.

Ancak daha önce de ifade edildiği gibi derste gösterilen çeviri yaklaşımları, yöntem ve stratejileri çeviri sürecine çeviri öğrencisi tarafından yansıtılmaya da çalışılmıştır. Ve kuram-uygulama bütünlüğü çerçevesinde öğrencinin zamanla uygulama oranı arttıkça daha başarılı çeviriler yapabileceği umulmaktadır.

Yapılan analizle bağlantılı olarak çeviri öğrencisi çevirisinin sonunda araştırma için İngilizce ve Türkçe koşut metinleri okuduğunu belirterek erek kitle olarak doktorlar ya da sağllk uzmanlarını seçtiğini ve bu nedenle de kelimesi kelimesine çeviri yaptığını, bilimsel terimleri ve cümleleri olduğu gibi çevirdiğini ve genel olarak kaynak odaklı yaklaşımı benimsediğini ileri sürmüştür.

\section{İkinci çeviri incelendiğinde;}

Tablo 2'de de görüleceği gibi Koronavirüs hakkındaki ilk cümle incelendiğinde kaynak metnin anlamı erek metne yansımakla birlikte, çeviri öğrencisi "new or novel coronavirus" ifadesi için erek dilde "şimdilerde" karşılığını kullanarak anlam çevirisi yapmıştır.

"Is the New Virus the same as SARS?" sorusunu erek dile "SARS virüsüyle aynı mı?" şeklinde çeviren öğrenci okurun neyin kastedildiğini anlayabileceğini düşünerek "the new virus" ifadesini erek dilde atmış (omission) ya da kullanmamıştır. Benzer şekilde üçüncü soruda erek dile "ne kadar tehlikeli?" şeklinde çevrilmiş ve "virüs" sözcügü atılmıştır.

\footnotetext{
12 Çeviri incelendiğinde bu hatalardan bazları görülebilir.
} 
"People with pre-existing medical conditions (such as, diabetes and heart disease) appear to be more vulnerable to becoming severely ill with the virus” ifadesi çeviri öğrencisi tarafından erek dile "Önceden tıbbi durumları var olan (diyabet ve kalp hastalığı gibi) kişiler virüse karşı ciddi şekilde yakalanmaya hassas görünmektedirler" şeklinde çevrilmiştir. Çeviri anlamı vermektedir ancak burada ifadelerin erek dile sözcüğü sözcüğüne aktarıldığı görülmektedir.

"Detailed investigations found that..." ifadesi erek dile "Ayrıntılı araştırmalar... buldu." Şeklinde çevrilmiştir. O halde çeviri öğrencisi bu cümlenin çevirisinde yine sözcü̆̆ü sözcüğüne çeviriyi yöntemini benimsemiştir. Anlam çevirisi yapıldığında erek dilde "detaylı araştırmalar ortaya çıkardı" denilebilirdi.

"Contamination" ifadesi erek dile "kontaminasyon" şeklinde çevrilmiştir. Bu da çevirmenin transliterasyon yoluyla ödünçleme yaptığını göstermektedir. Sözcüğün erek dildeki karşılı̆̆ı olarak "bulaşma" ifadesi de tercih edilebilirdi.

"Virüse kimler yakalanabilir?" sorusu altında "Those infected from other countries are among people who have recently traveled from China or who have been living or working closely with those travellers, such as family members, co-workers or medical professionals caring for a patientbefore they knew the patient was infected with 2019-nCoV ifadesi erek dilde çevrilmemiştir.

Benzer şekilde "who is at risk of develoğing severe illness?" sorusu ve altındaki açılamalar da erek dilde çevrilmemiştir. Bunun muhtemel nedeni zaten "ne kadar tehlikeli?” başlı̆̆ altında buradaki açılamaların yer alması olabilir.

"Virüs nasıl yayılır?" başlığı altında çeviri öğrencisi "the new coronavirus is a respiratory virus which spreads primarily through contact with an infected person through repiratory droplets generated when a person, for example, coughs or sneezes, or through droplets of saliva or discharge from the nose" ifadesi erek dile "Yeni koronavirüs, esas olarak enfekte olmuş bir kişiyle temas yoluyla, örneğin bir kişi öksürdüğünde veya hapşırdığında ortaya çıkan solunum damlacıkları yoluyla veya tükürük damlacıkları veya burun akıntısı yoluyla yayılan bir solunum virüsüdür." şeklinde çevrilmiştir. Anlam olarak çeviri doğru olsa da uzun cümle yapısının erek dilde sürdürülmesi, tıpkı makine çevirisinden çıkmış gibi sözcüğü sözcüğüne bir çeviriyle sonuçlanmıştır.

Genel olarak bakıldığında çeviride anlamsal hatalar bariz olmamakla beraber, metnin bilimsel nitelikte olmasından dolayı çeviri öğrencisi daha çok sözcü sözcüğüne çeviri yöntemini benimsemiş, ödünçlemelere başvurmuş ve bazı ifadelerin çevirisinde çıkarma yöntemini uygulamıştır. IMT 103 Çeviri ve Çeviribilme Giriş Dersinde öğretilen çevri yaklaşımlarının ve kuramsal yöntemlerin çeviri öğrencisi tarafından metnin türü ve özel yapısı da dikkate alındığında uygulandığı söylenebilir.

Çeviri öğrencisi çevirisinin sonunda koşut metinlerden (virüs aileleri, virüs çeşitleri, insanllğı en çok etkileyen virüsler, koronavirüs hakkında yazılmış yazllar vs.) yararlanarak erek kitlesi olarak doktor ve hastalığa yakalanma ihtimali olan kişileri hedeflediğini söylemiştir. Bu nedenle bazı ifadelerin çevirisinde İngilizce sözcükleri olduğu gibi bırakmış (söz gelimi contamination: kontaminasyon), bazı cümleleri de sözcüğü sözcüğüne açıllayarak teknik çevirinin özellikleri olan doğruluk, açıklık ve özlük yapısının çeviride korunmasına dikkat etmeye çalışmış görünmektedir. 


\section{Üçüncü çeviri incelendiğinde;}

Çeviri öğrencisi çeviriye kaynak metinde olmayan bir başlık ekleyerek (addition) başlamıştır: Yeni Tip Koronavirüsüne Dair Merak Edilenler. Öğrenci ayrıca "yazımızda koronavirüsüne dair merak edilenler hakkında bahsedeceğiz. Yazımızda bulabileceğiniz başlıklar şunlar” diyerek kaynak metinde olmayan ifadeler eklemeyi sürmüş ve kaynak metindeki sorulardan oluşan bir bölüm yaparak erek okuyucu metin okumaya geçmeden önce bilgilendirmeyi amaçlamıştır. Bu da çevirmenin çevirinin başında erek odaklı bir yaklaşım sergilemeyi tercih ettiği şeklinde algılanabilir

Çeviri öğrencisi kaynak metindeki "novel” sözcüğü için erek dilde “yeni tip” karşılı̆̆ını kullanmıştır. Bu da çevirmenin sözcüğü açımladığını göstermektedir.

Öğrenci ayrıca SARS ifadesini erek dilde "Şiddetli Akut Solunum Yolu Sendromu” olarak açıklamıştır. Bunun nedeni erek okurun metni daha net anlamasını sağlamak olabilir.

"How dangerous is it”? ifadesi erek dile "ne kadar tehlikeli bir virüsten bahsediyoruz?” şeklinde aktarılmıştır Bu da, çeviri metnin konuşma havası içinde olduğunu göstermektedir.

"Older people, and people with pre-existing medical conditions (such as, diabetes and heart disease) appear to be more vulnerable to becoming severely ill with the virus" ifadesi erek dile "Yaşı geçkin insanlar ve önceden mevcut hastalıkları (diyabet ve kalp hastalığı gibi) olan kişilerde ağır hastalık geçirme riski daha fazladır” şeklinde aktarılmıştır. Diğer iki çeviriyle kıyaslandığında, bu çevirinin de anlamı verdiği ileri sürülebilir. Bununla birlikte çeviri öğrencisi bu metnin çevirisinde anlamına göre çeviri yaklaşımını diğerlerine nazaran daha yoğun olarak uygulamış görünmektedir.

"Detailed investigations found that" ifadesi erek dile detaylı araştırmalar sonucunda tespit edilmiştir şeklinde aktarılmıştır. Kaynak metindeki etken yapı erek dilde edilgen olarak verilmiştir (Modülasyon).

"that have not yet infected humans" ifadesi erek metne ki bağlacıyla aktarılmış ve "ki [bu da] henüz insanları etkilememiştir” şeklinde bir karşılık verilmiştir.

"Surveillance" sözcüğü için erek dilde "keşif" kullanılmıştır. "Dünya genelinde keşifler geliştiğinden, daha fazla koronavirüsü tanımlanması mümkündür". Keşif sözcüğü akla coğrafi keşifleri getirmektedir. Burada kastedilen aslında araştırmalardır. Çevirmen hatalı bir sözcük seçimi yapmış görünmektedir.

"Detailed investigations found that SARS-CoV was transmitted from civet cats to humans in 2002 and MERS-CoV to humans in Saudi Arabia in 2012" ifadesi erek dile "detaylı araştırmalar sonucunda Koronavirüsü, bir misk kedisinden insanlara 2002 yllında Çin'de ve bir çöl devesinden Sudi Arabistan'[da], insanlara bulaştığı tespit edilmiştir" şeklinde aktarılmıştır. Burada bir anlam hatası ve cümle düşüklüğü göze çarpmaktadır.

“Epidemiology” ifadesi erek dile transliterasyon yoluyla “epidemiyoloji” şeklinde aktarılmıştır.

WHO kısaltması erek metinde “Dünya Sağlık Örgütü” şeklinde açıklanmıştır. 


\author{
"Respiratory droplets" erek metne respirator damlacıkları (solunum damlacıkları) şeklinde \\ aktarılmıştır.
}

Genel olarak bakıldığında çeviri öğrencisi IMT 103 Çeviri ve Çeviribilime Giriş dersindekiki öğrenme çlktılarını çeviri sürecine yansıtmış, ödünçleme, transliterasyon, modülasyon, sözcüğü sözcüğüne çeviri, anlam çevirisi, açlklama vb. yöntemlere başvurmuş ve çeviri amacı ve hedefi olarak erek odaklı bir çeviri gerçekleştirmeye çalışmıştır. Bunun için ayrıca çevirisinde "çevirmen notları" bölümü de kullanmıştır.

Bu çalışmada ders öğrenme çlktılarının çeviri sürecine yansıtılıp yansıtılmadığı incelendiğinden çeviri hataları tek tek açıklanmamakla beraber, çeviri öğrencisi bazı cümleleri aktarırken yazım noktalama ya da anlamsal hatalar da yapmıştır. Ancak genel anlamda, çevirinin isteneni verdiği söylenebilir.

Bununla paralel olarak çeviri öğrencisi Türkçe ifade edebilmek için birkaç koşut makale okuduğunu söylemiş ve çevirinin sonunda virüs hakkında ve tıp terimleriyle ilgili bilgisi olmayan vatandaşları ve hemşire gibi sağlık personellerini hedeflediğini açıllayarak çoğunlukla sözcüğü sözcüğüne çeviri yaklaşımıyla metnin bütünlüğüne bağlı kaldığını ve kaynak metindeki bazı ifadeleri erek metinde farklı cümle ve kelimeler seçerek kullanarak açıklamıştır.

\title{
Sonuç
}

$\mathrm{Bu}$ çalışmanın sonunda, öğrenci çevirileri de göz önünde bulundurularak, IMT 103 Çeviri ve Çeviribilime Giriş dersinin öğrenme çlktılarının, ders içeriğinde yer alan çeviri yöntem ve stratejilerinin, kuramsal yaklaşımların çeviri öğrencileri tarafından çeviri sürecine yansıtılabildiği ve bu bilgilerin özümsenme oranının kayda değer olduğu görülmüştür. O halde birinci sinıftan itibaren çeviri öğrencilerinin bu yaklaşımlarla desteklenmesi, kuram ve uygulama arasında bütünlük olması gerektiğinin öğrencilere aşılanması ve çeviri serüveninin ilk aşamasından itibaren çeviri sürecine aşinalık kazandırılması önem arz etmektedir. Yapılan analizlere bakıldığında üç öğrencinin de kaynak metni erek metne aktarırken temelde sözcüğ̈̈ sözcüğüne yaklaşımla farklı yöntem ve stratejiler de kullandığı ve çevirmen kararları aldığı görülmektedir. Çevirilerin her biri genel olarak anlamı aktarabilmiştir. Yer yer çeviri hataları ve bariz yanlış anlaşılmalar da elbette olmuştur. Bu normal olarak kabul edilmelidir. Zira öğrenciler daha birinci sınıf öğrencileridir ve henüz uzmanlıklarını kazanmamışlardır. Bu çalışmada asıl hedeflenenlerden biri, kuramsal yaklaşımların uygulamada işe yarayıp yaramadığını ortaya koymak ve uygulama olmadan da salt kuram öğrenmenin bir işlevinin olmadığını belirtmektir. Diğer hedefler arasında ise bu tarz kuram ve uygulama içerikli derslerin çeviri öğrencilerine katkı yapma potansiyeli olduğunu ortaya koymak, derslerde yöntemsiz ve kuramsız uygulama yaptırmanın yanlış bir tutum olduğunu ve bununla birlikte dersi salt teorik olarak işlemenin uygulama yaptırmadan bir faydasının olmayacağını belirtmektir. Bir diğer ifadeyle çeviri eğitiminde kuram derslerinin salt kuramsal anlatılmaması, uygulamayla desteklenmesi ve daha birinci sinıftan itibaren giriş düzeyinde de olsa kuramsal alt yapının oluşturulmaya başlaması için Çeviri Kuramları gibi derslerin ilk yarı yılda verilmesi ancak adının Çeviri Kuramları ve Uygulamaları şeklinde olması, ya da en azından içeriğin bunu hedef alması önem arz etmektedir. Son olarak bir gemi düşünelim. Kaptansız ilerlemez ancak dümensiz de yol alamaz.

\section{Kaynaklar}

A. Schwartz, David ve L. Graham, Ashley (2020), "Potential Maternal and Infant Outcomes from Coronavirus 2019-nCoV (SARS-CoV-2) Infecting Pregnant Women: Lessons from SARS, MERS, and Other Human Coronavirus Infection" Viruses 2020, 2.1-16. 
Çetintaş Sönmez, Esra (2011), Tip Metinlerinin Çevirisine İlişskin Yaklaşımlar be Beklentiler: Bir Olgu Çalışması, Okan Üniversitesi, Sosyal Bilimler Enstitüsü (Yüksek Lisans Tezi).

Erten, Asalet (2016), Trp Terminolojisi ve Trp Metinleri Çevirisi, Seçkin Yayın Evi.

Hastürkoğlu, Gökçen (2019), "Situated Learning in Translator and Interpreter Training: Model United Nations Simulations”, Journal of Language and Linguistic Studies, 15(3), 914-925; 2019.

Karwacka, Wioleta (2015), Medical Translation, In: Ł. Bogucki, S. Gozdz-Roszkowski, P. Stalmaszczyk (eds.) Ways to Translation. Wydawnictwo Uniwersytetu Łódzkiego, s.271-298.

M. Argeg, Gharsa (2015), The Problems of Translating Medical Terms from English into Arabic, School of Modern Languages and Cultures (Phd dissertation).

Rigouts Terryn, Ayla ve diğ. (2019), "Pilot Study on Medical Translations in Lay Language:PostEditing by Language Specialists,Domain Specialists or Both?", Translating and the Computer 41 (London Conference), s.101-112.

T.C. Sağlık Bakanlığı Halk Sağlığı Genel Müdürlüğü (Ocak, 2020), 2019-nCoV HASTALIĞI, Sağhk Çalışanları Rehberi, https://hsgm.saglik.gov.tr/depo/birimler/Bulasici-hastaliklardb/hastaliklar/2019_n_CoV/rehberler/2019-nCoV_Hastaligi_Rehberi_.pdf

Erişim: 14.01.2020.

“Öğrenme Çıktıları ve Ders Detayı", http://ubys.bartin.edu.tr/AIS/OutcomeBasedLearning/Home/CourseDetail?\&isElectiveCourse $=$ false\&isIntegratedCourse $=$ false $\&$ courseId $=33826 \&$ curriculumId $=500748 \&$ apid $=512 \&$ eqd $=10$ 602\&progName=Edebiyat\%20Fak\%C3\%BCltesi\%20-

\%20\%C3\%87eviribilim\%2oB\%C3\%B6l\%C3\%BCm\%C3\%BC\%20/\%20\%C3\%87eviribilim\%2oPr. \%20(\%C4\%Bongilizce) Erişim: 25.02.2020

"Koronavirüs", https://www.who.int/news-room/q-a-detail/q-a-coronaviruses Erişim: 05.01.2020 